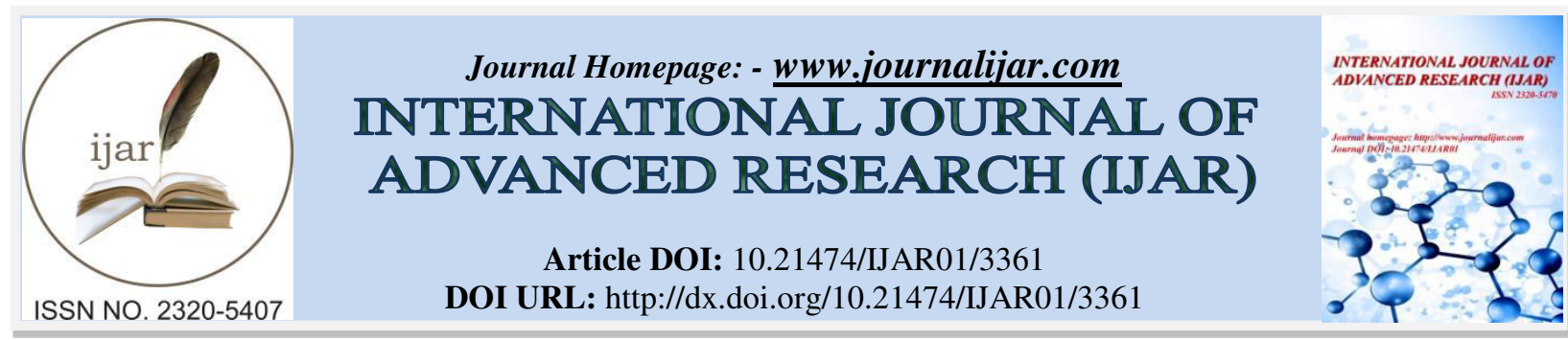

RESEARCH ARTICLE

\title{
HISTOPATHOLOGICAL SPECTRUM OF SALIVARY GLAND TUMOURS: A HOSPITAL BASED STUDY.
}

\author{
*Syed Imtiyaz Hussain ${ }^{1}$, Gulshan Akhter ${ }^{2}$, Farooq sideeq ${ }^{3}$, Baba Iqbal ${ }^{1}$, Ruby Reshi ${ }^{4}$, Farzana Manzoor $^{3}$ \\ and Arshi Beg ${ }^{3}$. \\ 1. Senior resident Post graduate department of Pathology Gmc Srinagar.
}

2. Senior resident Post graduate department of Obstetrics and Gynaecology Gmc Srinagar.

3. Post graduate scholar Post graduate department of Pathology Gmc Srinagar.

4. Head of Department Post graduate department of Pathology Gmc Srinagar. 190010.

\section{Manuscript Info}

Manuscript History

Received: 29 December 2016

Final Accepted: 28 January 2017

Published: February 2017.

Key words:-

Salivary gland tumors, Pleomorphic adenoma, Adenoid cystic carcinoma.

\section{Abstract}

Background: Salivary gland tumors are common neoplasms of head and neck region. These tumors are complex and some of them exhibit great deal of morphologic overlap . The majority of these neoplasms are benign. These tumours can occur in both major and minor salivary glands. $80 \%$ of major salivary gland tumours occur in the parotid glands, while most minor salivary tumours are located in the palate. As a general rule in clinical practice, the smaller the salivary gland is, the more likely the tumour is malignant.

Objective: This study was carried out to study the histopathological spectrum of salivary gland tumors and to know their pattern of distribution.

Material and Methods:- This is a two year retrospective study which was conducted in the Post graduate department of pathology Government Medical College Srinagar from January 2015 to December 2016 . Post surgical specimens were studied in detail to know the histological patterns. In each patient, age, sex, site and histopathological diagnosis was seen from record section of the department. The histological diagnosis of each individual tumor was based on the 2005 WHO classification of salivary gland tumors.

Results:- During two year ( from January 2015 to December 2016), 100 cases of salivary gland tumors were diagnosed with peak incidence in third to fourth decade $(48 \%)$.Among these, $63(63 \%)$ cases were benign and $31(31 \%)$ cases were malignant. The commonest site was parotid gland $(68 \%)$ followed by submandibular glands $(19 \%)$ and minor salivary gland tumors were $13 \%$. 


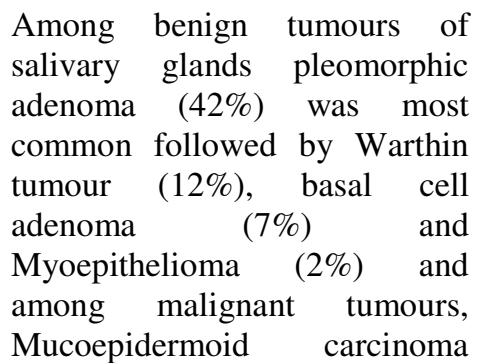

(46\%) was most common followed by Adenoid cystic carcinoma (32.5\%), Carcinoma ex pleomorphic adenoma (10.8\%), Acinic cell carcinoma and Polymorphous low grade adenocarcinoma each comprising of (5.4\%).

Conclusion: Histopathological study of salivary gland lesions is the most important method in establishing the final diagnosis and accordingly guides in the specific management.

Copy Right, IJAR, 2017,. All rights reserved.

\section{Introduction:-}

Salivary gland neoplasms are rare lesions and represent less than $1 \%$ of all tumors and 3-5.5\% of all head and neck tumors $^{\mathbf{1 , 2}}$. These comprise a wide variety of benign and malignant neoplasms, which exhibit difference not only in biological behavior but in prognosis as well. Tumours of salivary glands have the most varied spectrum. Approximately $80 \%$ of the salivary gland tumors are found in the Parotid gland and 10 to $15 \%$ in the submandibular gland. Majority of Salivary gland tumours are of benign histology (80-85\%), with pleomorphic adenoma being the most common, ${ }^{3}$ constituting $70 \%$ of benign tumours.

The mean age of patients with salivary gland tumours is 50 years with a peak in 6 th and 7 th decades of life $e^{\mathbf{4 , 5}}$. Benign Salivary gland tumours occur more frequently in females whereas malignant tumors occur mostly in males ${ }^{6,7}$. Parotid gland is the most common site comprising about $70 \%$ of all salivary gland tumors ${ }^{\mathbf{8}}$. Benign tumours mostly occur in the parotid gland comprising of about $80 \%$ most common being pleomorphic adenoma followed by Warthin tumor ${ }^{6}$. The most common malignant salivary gland tumour is the Mucoepidermoid carcinoma which involves mostly the parotid gland followed by the minor and submandibular gland? Adenoid cystic carcinoma (originally known as cylindroma) is a generally slow growing but highly malignant neoplasm with a remarkable capacity for recurrence. In the parotid gland it is less common than the mucoepidermoid carcinoma and acinic cell carcinoma, but in the minor salivary glands it is the most common malignant tumour ${ }^{\mathbf{1 0}}$. Acinic cell carcinoma comprises of $1-3 \%$ of all salivary gland tumour. There is a male predominance and a peak incidence in the third decade of life. ${ }^{11}$

\section{Aims and Objectives:- \\ $>$ To study histopathological spectrum of Salivary gland tumours. \\ $>$ To classify benign and malignant lesions according to WHO Classification. \\ $>$ To study the age, sex and site distribution of various salivary gland lesions.}

\section{Materials and Methods:-}

This is two year retrospective study which was conducted in the post graduate department of pathology in Govt. medical college Srinagar from January 2015 to December 2016, which included 100 cases of salivary gland tumours which were received in our department .These specimens were subjected to the routine processing and paraffin embedding. The sections were stained with routine Hematoxylin and Eosin $(\mathrm{H} \& \mathrm{E})$ and examined. The relevant patient data such as age, sex, location of the tumor and histopathological diagnosis were taken from the record section of our department .The neoplastic lesions were classified according to the World Health Organization's histological typing of salivary gland tumors (2005).

\section{Results and Observations:-}

In our study we received 100 cases of salivary gland tumours during two year period from January 2015 to December 2016, in which 63 cases (63\%) were benign and 37 (37\%) were malignant. Males predominate and were 69 cases (69\%) where as females comprising of 31 cases (31\%). Male to Female ratio was $2.2: 1$. The age range was from 17 to 77 years.

Among the all salivary gland lesions, the commonest lesion was pleomorphic adenoma which comprised of $42 \%$ of all lesions. Among benign salivary gland tumours pleomorphic adenoma was most common (42\%) followed by warthin tumour (12\%), basal cell adenoma (7\%) and Myoepithelioma (2\%). Similarly among malignant salivary gland tumours, Mucoepidermoid carcinoma was most common(17\%) followed by Adenoid cystic carcinoma (12\%), Carcinoma ex pleomorphic adenoma (4\%), Acinic cell carcinoma and Polymorphous low grade adeno carcinoma 
each comprising of $2 \%$ of cases. Among benign salivary gland tumours pleomorphic adenoma (47.6\%), Warthin tumour $(17.4 \%)$ and basal cell adenoma (8\%) was most common in parotid gland.

From age wise distribution, it is observed that benign tumours of salivary glands were common in the second to fourth decade of life and malignant tumours were common from 5th decade onwards. Mucoepidermoid carcinoma was more common in males than in females with a male to female ratio of 3.2:1. Parotid was the most common site of occurrence for mucoepidermoid carcinoma (70.58\%) followed by minor salivary glands (17.64\%) and submandibular gland (11.76\%). Of all 17 cases of mucoepidermoid carcinomas 9 cases $(53 \%)$ were high grade, 5 cases $(29.5 \%)$ were intermediate grade and 3 cases $(17.6 \%)$ were low grade.

Adenoid cystic carcinoma was the second most common malignant salivary gland tumor (12\%). Minor salivary glands $(41.6 \%)$ were the most common site followed by submandibular gland (33.3\%) and parotid gland (25\%). Mucoepidermoid carcinoma (32.4\%) and Carcinoma ex-pleomorphic adenoma (10.8\%) were most most in parotid gland where as adenoid cystic carcinoma (13.5\%) was most common in minor salivary gland.

In our study male preponderance was seen in overall salivary gland lesions, but in benign tumours female predominance was seen 24 cases $(38 \%)$. In malignant salivary gland tumours, there was an overall male predominance 30 cases $(81 \%)$.

Table 1:- Age distribution of salivary gland tumours.

\begin{tabular}{|c|c|c|c|}
\hline Age group(years) & Total no.of patients & Benign tumours & Malignant tumours \\
\hline$<20$ & 7 & 7 & 0 \\
\hline $21-30$ & 21 & 18 & 3 \\
\hline $31-40$ & 26 & 20 & 9 \\
\hline $41-50$ & 22 & 4 & 10 \\
\hline $51-60$ & 14 & 1 & 9 \\
\hline$>60$ & 10 & & \\
\hline
\end{tabular}

Table 2:- Site wise distribution of salivary gland tumours.

\begin{tabular}{|c|c|c|c|}
\hline Parotid gland & Submandibular gland & Minor salivary glands & Total \\
\hline 68 & 19 & 13 & 100 \\
\hline
\end{tabular}

Table 3:- Distribution of benign salivary gland tumours.

\begin{tabular}{|c|c|c|c|c|}
\hline Tumour type & Parotid gland & $\begin{array}{c}\text { Submandibular } \\
\text { gland }\end{array}$ & $\begin{array}{c}\text { Minor salivary } \\
\text { glands }\end{array}$ & Total (out of 100) \\
\hline Pleomorphic adenoma & $30(47.6 \%)$ & $9(14.2 \%)$ & $3(4.7 \%)$ & $42(42 \%)$ \\
\hline Warthin tumour & $11(17.4 \%)$ & $1(1.5 \%)$ & 0 & $12(12 \%)$ \\
\hline Basal cell adenoma & $5(8 \%)$ & $2(3 \%)$ & 0 & $7(7 \%)$ \\
\hline Myoepithelioma & $1(1.5 \%)$ & $1(1.5 \%)$ & 0 & $2(2 \%)$ \\
\hline
\end{tabular}


Table 4:- Distribution of malignant salivary gland tumours

\begin{tabular}{|l|c|c|c|c|}
\hline \multicolumn{1}{|c|}{ Tumour type } & Parotid gland & $\begin{array}{c}\text { Submandibular } \\
\text { gland }\end{array}$ & $\begin{array}{c}\text { Minor salivary } \\
\text { glands }\end{array}$ & $\begin{array}{c}\text { Total } \\
(\text { out of 100) }\end{array}$ \\
\hline Mucoepidermoid carcinoma & $12(32.4 \%)$ & $2(5.4 \%)$ & $3(8 \%)$ & $17(17 \%)$ \\
\hline Adenoid cystic carcinoma & $3(8 \%)$ & $4(10.8)$ & $5(13.5 \%)$ & $12(12 \%)$ \\
\hline Acinic cell carcinoma & $2(5.4 \%)$ & 0 & $2(2 \%)$ \\
\hline $\begin{array}{l}\text { Polymorphous low grade } \\
\text { adenocarcinoma }\end{array}$ & 0 & 0 & $2(2 \%)$ \\
\hline $\begin{array}{l}\text { Carcinoma pleomorphic } \\
\text { adenoma }\end{array}$ & $4(10.8 \%)$ & 0 & 0 & $4(4 \%)$ \\
\hline
\end{tabular}

Table 5:- Distribution of Salivary gland tumors according to sex and site.

\begin{tabular}{|c|c|c|c|c|c|c|c|}
\hline \multirow{2}{*}{} & \multicolumn{2}{c|}{$\begin{array}{c}\text { Parotid } \\
\text { Gland }\end{array}$} & \multicolumn{2}{c|}{$\begin{array}{c}\text { Submandibular } \\
\text { Gland }\end{array}$} & \multicolumn{2}{c|}{$\begin{array}{c}\text { Minor salivary } \\
\text { Glands }\end{array}$} \\
\hline Sex & Total & Benign & Malignant & Benign & Malignant & Benign & Malignant \\
\hline Males & $69(69 \%)$ & $29(46 \%)$ & $18(48.6 \%)$ & $8(12.6 \%)$ & $5(13.5 \%)$ & $2(3 \%)$ & $7(19 \%)$ \\
\hline Females & $31(31 \%)$ & $18(28.5)$ & $3(8 \%)$ & $5(8 \%)$ & $1(2.7 \%)$ & $1(1.5 \%)$ & $3(8 \%)$ \\
\hline
\end{tabular}

Table 6:- Age wise distribution of Salivary gland tumors.

\begin{tabular}{|c|c|c|c|c|c|c|c|}
\hline $\begin{array}{c}\text { Salivary gland } \\
\text { tumours }\end{array}$ & $<20$ years & $\begin{array}{c}\mathbf{2 1 - 3 0} \\
\text { years }\end{array}$ & $\begin{array}{c}\mathbf{3 1 - 4 0} \\
\text { years }\end{array}$ & $\begin{array}{c}\mathbf{4 1 - 5 0} \\
\text { years }\end{array}$ & $\begin{array}{c}\mathbf{5 1 - 6 0} \\
\text { years }\end{array}$ & $\mathbf{> 6 0}$ years & Total \\
\hline $\begin{array}{c}\text { Pleomorphic } \\
\text { adenoma }\end{array}$ & 5 & 10 & 14 & 10 & 2 & 1 & 42 \\
\hline Warthin tumour & 2 & 5 & 2 & 1 & 2 & 0 & 12 \\
\hline $\begin{array}{c}\text { Basal cell } \\
\text { adenoma }\end{array}$ & 0 & 2 & 4 & 1 & 0 & 0 & 7 \\
\hline Myoepithelioma & 0 & 1 & 0 & 1 & 0 & 0 & 2 \\
\hline $\begin{array}{c}\text { Mucoepidermoid } \\
\text { carcinoma }\end{array}$ & 0 & 1 & 3 & 4 & 5 & 4 & 17 \\
\hline $\begin{array}{c}\text { Adenoid cystic } \\
\text { carcinoma }\end{array}$ & 0 & 2 & 2 & 3 & 2 & 3 & 12 \\
\hline $\begin{array}{c}\text { Acinic cell } \\
\text { carcinoma }\end{array}$ & 0 & 0 & 1 & 0 & 0 & 1 & 2 \\
\hline $\begin{array}{c}\text { Polymorphous } \\
\text { low grade } \\
\text { adenocarcinoma }\end{array}$ & 0 & 0 & 0 & 2 & 0 & 0 & 2 \\
\hline $\begin{array}{c}\text { Carcinoma ex } \\
\text { pleomorphic } \\
\text { adenoma }\end{array}$ & 0 & 0 & 0 & 0 & 3 & 1 & 4 \\
\hline
\end{tabular}


Table 7:- Gender wise distribution of salivary gland tumours

\begin{tabular}{|c|c|c|c|}
\hline Salivary gland tumours & Male & Female & M:F \\
\hline Pleomorphic adenoma & 27 & 15 & $1.8: 1$ \\
\hline Warthin tumour & 6 & 6 & $1: 1$ \\
\hline Basal cell adenoma & 4 & 3 & $2: 1$ \\
\hline Myoepithelioma & 2 & 4 & $3: 2: 1$ \\
\hline $\begin{array}{c}\text { Mucoepidermoid } \\
\text { carcinoma }\end{array}$ & 13 & 2 & $1: 1$ \\
\hline Adenoid cystic carcinoma & 10 & 1 & $2: 0$ \\
\hline Acinic cell carcinoma & 1 & 0 & $4: 0$ \\
\hline $\begin{array}{c}\text { Polymorphous low grade } \\
\text { adenocarcinoma }\end{array}$ & 2 & 0 & $2.2: 1$ \\
\hline $\begin{array}{c}\text { Carcinoma ex pleomorphic } \\
\text { adenoma }\end{array}$ & 4 & 31 & \\
\hline Total & 69 & 0 & \\
\hline
\end{tabular}

PHOTO MICROGRAPHS:-

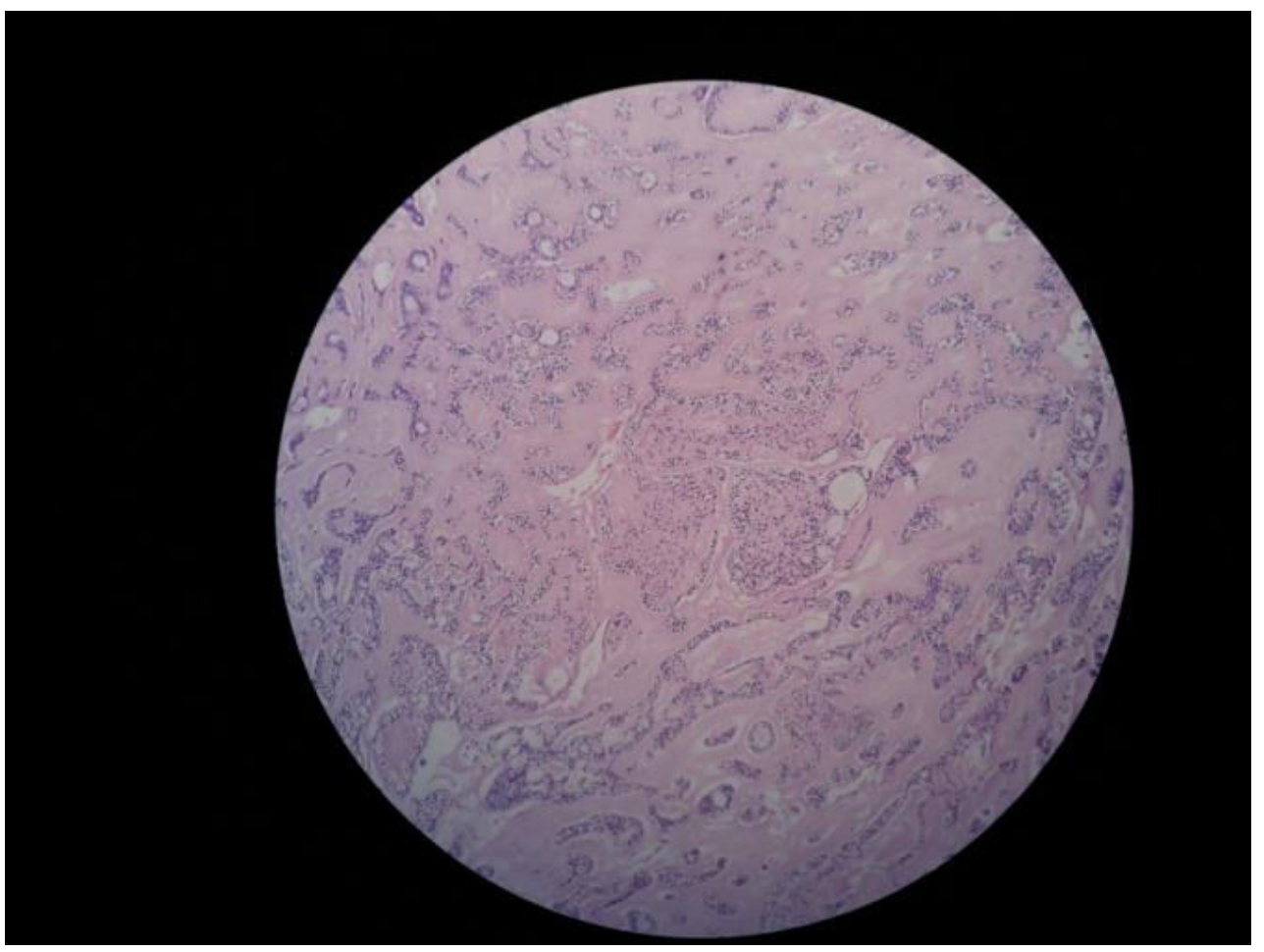

Photo Micrograph 1:- Microscopic appearance of Pleomorphic adenoma showing both epithelial and mesenchymal components. H\&E stain (10X). 


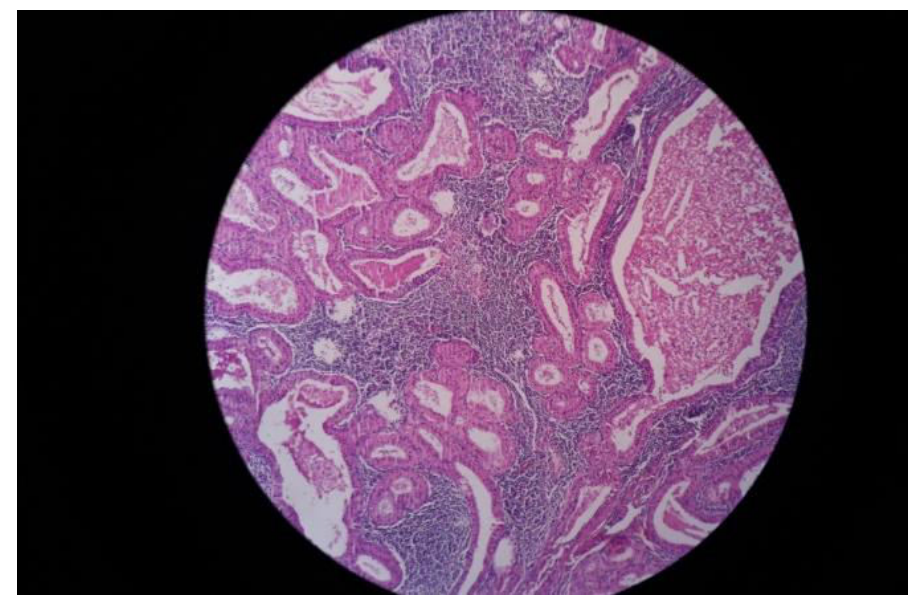

Photo Micrograph 2:- Microscopic appearance of Warthin tumour showing oncocytic lined epithelium and lymphoid stroma. H\&E stain (10X).

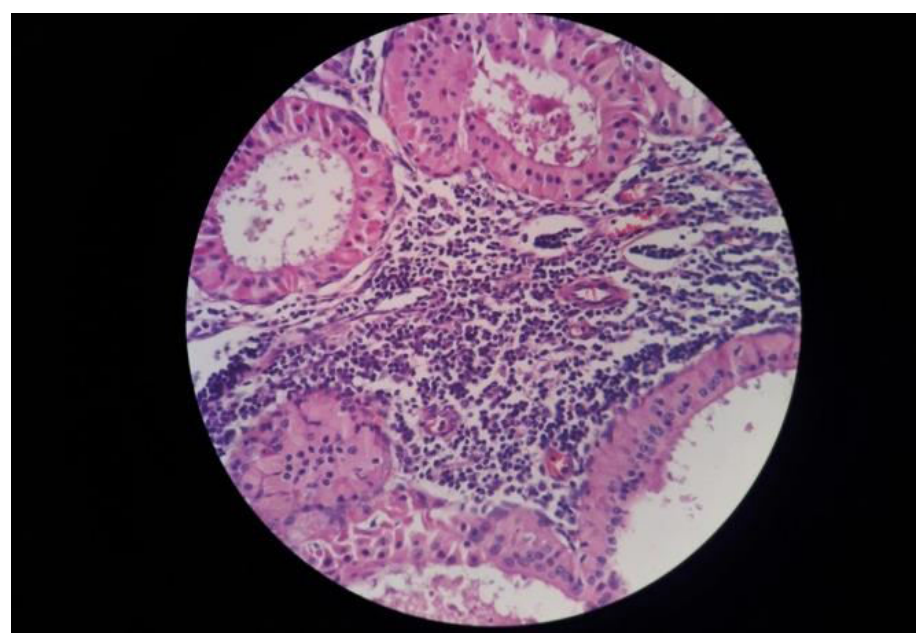

Photo Micrograph 3:- Microscopic appearance of Warthin tumour showing oncocytic lined epithelium and lymphoid stroma. H\&E stain (40X).

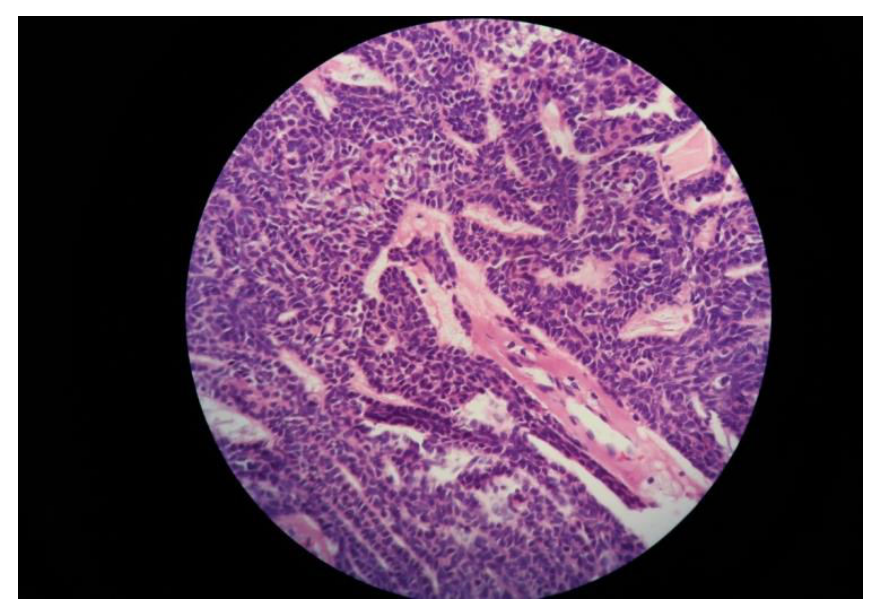

Photo Micrograph 4:- Microscopic appearance of Basal cell adenoma showing basaloid cells arranged in tubular pattern. H\&E stain (40X). 


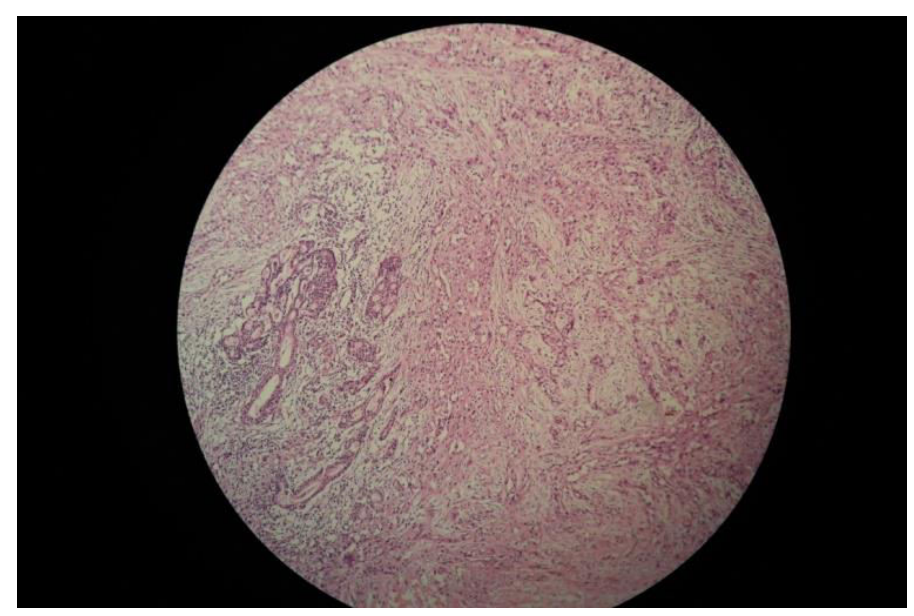

Photo Micrograph 5:- Microscopic appearance of Mucoepidermoid Carcinoma showing epidermoid cells and mucous cells. H\&E stain (10X).

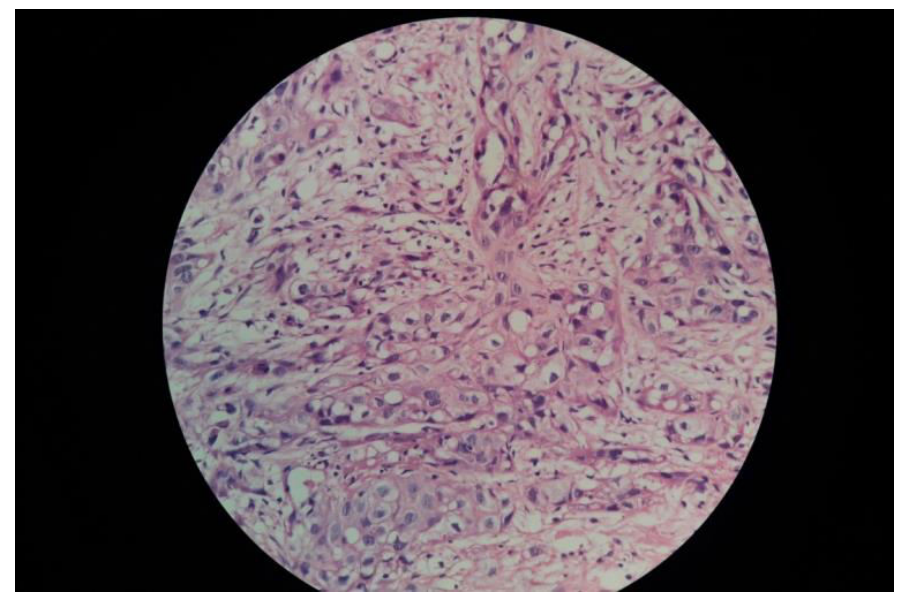

Photo Micrograph 6:- Microscopic appearance of Mucoepidermoid Carcinoma showing epidermoid cells and mucous cells. H\&E stain (40X)

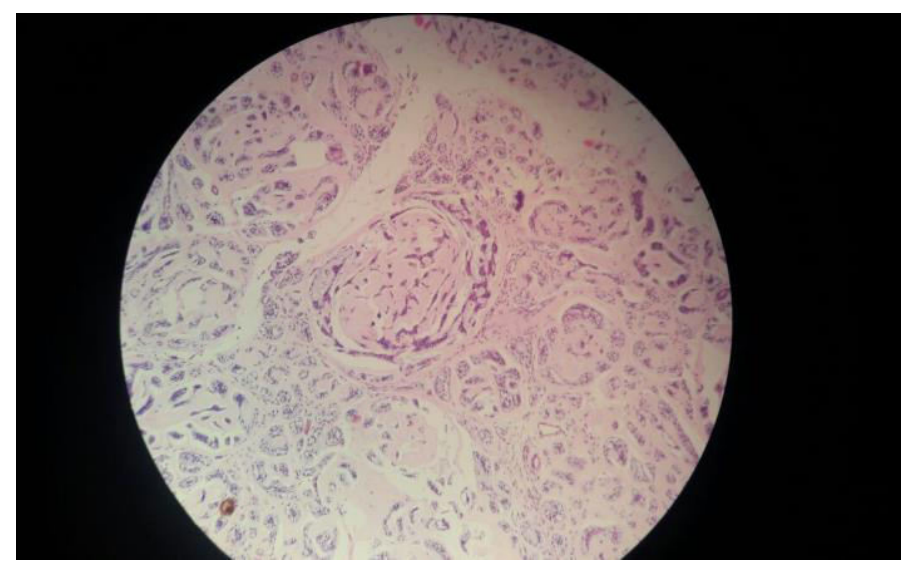

Photo Micrograph 7:- Microscopic appearance of Adenoid cystic carcinoma showing small cells arranged around gland like spaces. H\&E stain (10X). 


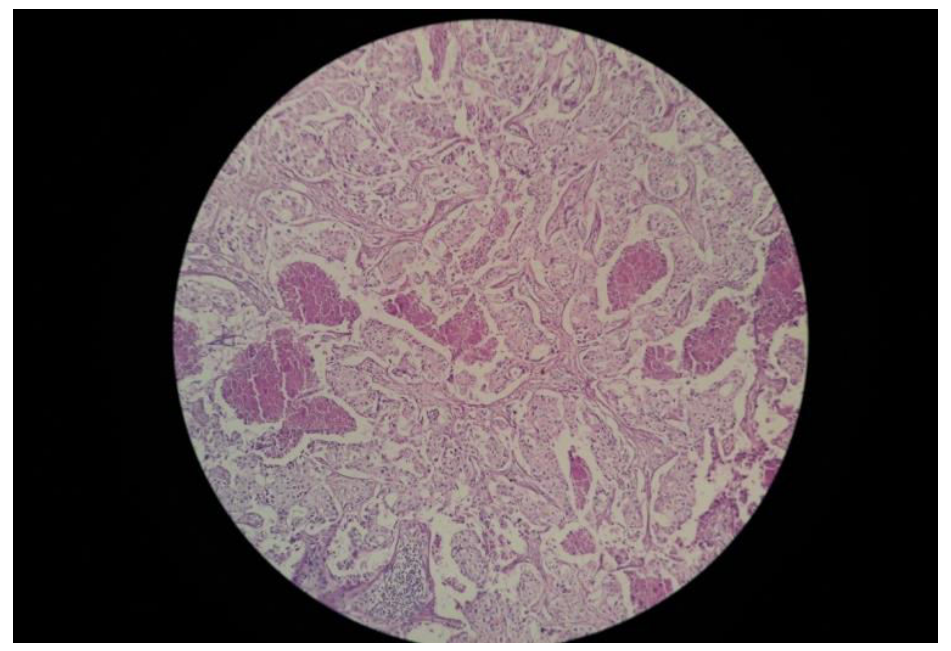

Photo Micrograph 8:- Microscopic appearance of Carcinoma ex Pleomorphic adenoma showing malignant epithelial component and areas of necrosis. H\&E stain (10X).

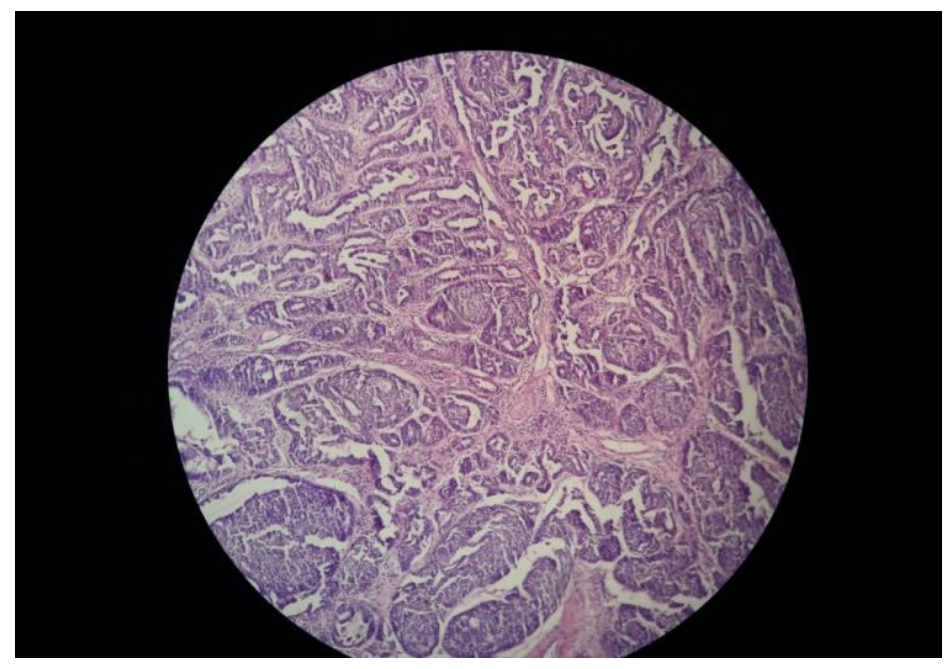

Photo Micrograph -9:- Microscopic appearance of Polymorphous low grade adenocarcinoma showing malignant epithelial glands. H\&E stain (10X)

\section{Discussion:-}

In the present study out of 100 cases of salivary gland tumors, 63(63\%) were benign and 37 (37\%) were malignant. This observation was comparable to the studies including case series by Nepal A et al. ${ }^{12}$, Ali NS et al. ${ }^{13}$, and Moghadam SA et al. ${ }^{14}$ where they noted a predominance of benign tumors over the malignant ones. The peak incidence of benign tumours in our study was between second to fourth decade which is similar to the other studies in the Asian subcontinent ${ }^{15,16}$. The peak incidence of malignant tumors in our study was seen in the fifth decade onwards which is similar to the other studies in the literature ${ }^{17,18}$. 
In the present study $\mathrm{M}$ : F ratio of malignant salivary gland tumours was $4.2: 1$ which is higher than the studies conducted by Ahmed et al ${ }^{19}$ (M:F ratio 1.1:1), Mohd Ayub et al ${ }^{20}$ (M:F ratio 2.25:1) and Iqbal MS et al ${ }^{21}(\mathrm{M}: \mathrm{F}$ ratio 2:1).

In our study parotid gland was the commonest site of tumours (68\%) followed by submandibular gland (19\%) and Minor salivary glands (13\%) which is almost same as studied by Ahmed et $\mathrm{al}^{\mathbf{1 9}}$, Pablo et $\mathrm{al}^{\mathbf{2 2}}$, Rewusuwan et $\mathrm{al}^{\mathbf{2 3}}$ and Bashir S et $\mathrm{al}^{\mathbf{2 4}}$.

Out of total 42 pleomorphic adenomas in our study, majority occurred in the parotid gland 30cases (71.42\%) followed by submandibular gland 9 cases (21.42\%) and minor salivary glands 3 cases (7.14\%). Potdar and Paymaster $^{25}$ reported 183 cases of pleomorphic adenomas, out of which 101 were involving parotid gland (55\%).

Benign salivary gland tumours $(63 \%)$ predominate over the malignant salivary gland tumours $(37 \%)$. The study conducted by Deepak Soni et $\mathbf{a l}^{\mathbf{2 6}}$ shows it to be $69.33 \%$ and $30.66 \%$ respectively. Pleomorphic adenoma was the most common salivary gland tumour accounting for $42 \%$ of all tumours and $66.6 \%$ of all benign tumours. Almost similar results were obtained by the study conducted by Bhavani $\mathrm{K}$ et $\mathrm{al}^{27}$. The male female ratio of pleomorphic adenoma was 1.8:1.The result was comparable with the result obtained by Vergas et al $^{28}$ which showed male female ratio of 2:1.

Warthin tumour comprising of $12 \%$ of all salivary gland tumours and $19 \%$ of all benign tumours. The study conducted by Pablo et al ${ }^{22}$ shows it to be $10.48 \%$ and $13 \%$ respectively.

91.6\% of Warthin tumour were found in the parotid gland which were almost similar to the results obtained by Mohd Ayoub et $\mathrm{al}^{\mathbf{2 0}}$ and Bashir et $\mathrm{al}^{\mathbf{2 4}}$.

Mucoepidermoid carcinoma was the most common malignant tumour comprising of $27 \%$ of total malignant salivary

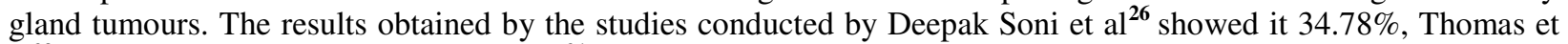
$\mathrm{al}^{\mathbf{2 9}}$ showed it $34.73 \%$ and Iqbal MS et $\mathrm{al}^{\mathbf{2 1}}$ showed it $40 \%$. The peak incidence of Mucoepidermoid carcinoma was seen in 40-60 years with male predominance and male female ratio of 3.2:1 which correlates with the study conducted by Deepak Soni et $\mathrm{al}^{\mathbf{2 6}}$.

In our study Parotid gland was the most common site $(70 \%)$ for mucoepidermoid carcinoma followed by minor salivary glands $(17.6 \%)$ and submandibular gland $(11.7 \%)$. Richardson et al $^{\mathbf{3 0}}$ reported 52 cases of mucoepidermoid carcinoma in the parotid gland out of 61 cases $(85 \%)$.

In our study Adenoid cystic carcinoma comprising of $19 \%$ of all malignant salivary gland tumours which correlates with the study done by Deepak Soni et $\mathrm{al}^{\mathbf{2 6}}(21.73 \%)$

Minor salivary glands were the most common site of adenoid cystic carcinoma (41\%) followed by submandibular gland $(33.3 \%)$ and parotid gland $(25 \%)$. Rewusuwan et $\mathrm{al}^{\mathbf{2 3}}$ found submandibular gland to be the most common site of adenoid cystic carcinoma in their study.

Carcinoma ex pleomorphic adenoma comprises of $10.8 \%$ of all malignant salivary gland tumours which correlates to the study conducted by Deepak Soni et al ${ }^{\mathbf{2 6}}$

\section{Conclusion:-}

Salivary gland tumours exhibit broad histopathological spectrum. Benign tumours are more common than malignant tumours with Parotid gland being the most common site and Pleomorphic adenoma the most common tumour type. The hurdle in their management lies in the difficulty in distinguishing between benign and malignant tumours.

\section{Acknowledgement:-}

Authors acknowledge the immense help received from the scholars whose articles are cited and included in references of this manuscript. The authors are also grateful to authors / editors / publishers of all those articles, journals and books from where the literature for this article has been reviewed and discussed. 


\section{Bibliography:-}

1. Pons-Vicente O, Almendros-Marques N,Berini-Aytes L, Gay Escoda C. Minor salivary gland tumors:A clinicopathological study of 18 cases. Med Oral Pathol Oral CirBucal2008; 13:582-8.

2. Ethunandan M, Davies B, Pratt CA, Puxeddu R, Brennan PA. Primary epithelial submandibular salivary gland tumors - Review of management in a district general hospital setting. Oral Oncol2009;45:173-6.

3. Spiro 2001 JD, SpiroRH, Salivarytumors, In ShahJP, DeckerSBC,ed;Cancer of the head \& neck:2001;240- 250.

4. Eveson JW, Cawson RA. Salivary gland tumors. A review of 2410 cases with particular reference to histological types, site, age and sex distribution. J Pathol., 1985; 146: 51-8.

5. Auclair PL, Ellis GL, Gnepp DR, Wenig BN, Janey CG. Salivary gland neoplasms: general considerations. In: Ellis GL, Auclair PL, Gnepp DR, editors. Surgical pathology of the salivary glands. Philadelphia: WB Saunders; 1991, p. 135-64.

6. Nagler RM, Laufer D. Tumors of the major and minor salivary glands: review of 25 years of experience. Anticancer Res., 1997; 17: 701-7.

7. Pinkston JA, Cole P. Incidence rates of salivary gland tumors: results from a population-based study. Otolaryngol Head Neck Surg., 1999; 120: 834-40.

8. Yu GY, Ma DQ. Carcinoma of the salivary gland: a clinicopathologic study of 405 cases. Semin SurgOncol., 1987; 3: 240-4.

9. Pires FR, Almeida OP, de Araujo VC, Kowalski LP. Prognostic factors in head and neck mucoepidermoid carcinoma. Arch Otolaryngol Head Neck Surg., 2004; 130: 174-80.

10. Rosai, J. 2011. major and minor salivary glands. :Rosai and Ackerman's Surgical Pathology. 10th Edn.; Mosby: An Imprint of Elsevier, Missouri, pp 817- 840.

11. AbraAM, CornynJ,Scofield HH, Hansen LS. Acinic cell adenocarcinoma of the major salivary glands.A clinicopathological study of 77 cases.Cancer 1965,18: 1145-1162.

12. Nepal A, Chettri ST, Joshi RR, Bhattarai M, Ghimire A, Karki S; Primary Salivary Gland Tumors in Eastern Nepal Tertiary Care Hospital; J Nepal Health Res Counc 2010;8:31-4.

13. Naeem Sultan Ali, Ahmad Nawaz, Shaheryar Rajput, Mubasherlkram. Parotidectomy: A Review of 112 Patients Treated at a Teaching Hospital in Pakistan; Asian Pacific Journal of Cancer Prevention 2010;11.

14. SaedeAtarbashiMoghadam, FazeleAtarbashiMoghadam, Mehdi Dadfar. Epithelial Salivary Gland Tumors in Ahvaz, Southwest of Iran; J Dent Res Dent Clin Dent Prospect 2010; 4:120-23.

15. Satko I, Stanko P, Longauerova I. Salivary gland tumors treated in the stomatological clinics in Bratislava. J Craniomaxillofac Surg., 2000; 28: 56-61.

16. Rahrotaban S, Masoomi P, Moradi M, et al. Frequency of salivary gland tumors in two referral center of Qazvin university of Medical sciences from 1999-2009. J Res Dent Sci., 2009; 2: 27-31.

17. Lima SS, Soares AF, de Amoriom RF, et al. Epidemiologic profile of Salivary gland tumors: analysis of 245 cases. Braz J Otorrinolaringol., 2005; 71: 335-40.

18. Luukkaa H, Klemi P, Leivo I, et al. Salivary gland cancer in Finland 1991-96: an evaluation of 237 cases. ActaOtolaryngol., 2005; 125: 207-14. 
19. Ahmad S, Lateef M, Ahmad R. Clinicopathological study of primary salivary gland tumors in Kashmir. JK Practitioner 2002; 9(4):231- 233.

20. Mohammed Ayub M, Zahid S, Abbas Z and Shoukat M. Morphological pattern of parotid tumors. Journal of the College of Physicians and Surgeons 2008; 18(5):274- 277.

21. Iqbal MS, Tabassum A, Chatura. K R, Malkappa S K, Basavaraja P K. Histomorphological study of salivary gland neoplasms: a 2 year study. Journal of Evolution of Medical and Dental Sciences,2013, Jan;2(4):315-324.

22. Pablo Agustin Vargas, Rene Gerhard, Vergilius JF AraijoFalho and Ines Vieiro de Castro. Salivary gland tumors in Brazilian population: A retrospective study of 124 cases. Rev Hos ClinFac Med S Paulo 2002; 57(6):271-276.

23. Rewusuwan S, Settakorn J, Mahanupab P, Salivary gland tumors in MaharajNakorn Chiang Mai hospital: A retrospective study of 198 cases. Chiang Mai Med Bull 2006; 45(2):45-43.

24. Bashir S, Mustafa F, Malla H A, Khan A H, Rasool M, Sharma S. Histopathological Spectrum of Salivary Gland Tumors: A 10 Year Experience. Sch. J. App. Med. Sci., 2013; 1(6):1070-1074.

25. Potdar GG, Paymaster JC. Tumors of salivary glands. Am J Surg 1969;118:440.

26. Deepak Soni,KusumMathur et al .Histopathological spectrum of salivary gland lesions in tertiary care centre.Int J Med Res Prof 2016;2(2);209-15.

27. BhavaniK,Urs RAN et al.Histopathological study of Salivary gland tumours.J.Evolution Med.Dent.Sci.2016; $5(72):$ 5240-5244.

28. Pablo Agustin Vergas, Rene Gerhard, Vergilius J. F. AraujoFiliho and Ines Vieira de Castro; Salivary gland tumors in Brazillian population: A retrospective study of 124 cases. Rev. Hosp. Clin. Fac. Med. S. PAULO 2002; 57(6):271-276.

29. Thomas K M, Hutt M S R and Borgestein J. Salivary gland tumors in Malawi. Cancer 1980; 46:2328-2334.

30. Richardson GS, Dickason WL, Gaisford JC, et al. Tumors of salivary glands; An analysis of 752 cases. Plastic Reconstr Surg 1975;55:131. 